\title{
KEBIJAKAN PELAYANAN PENGURUSAN SERTIFIKAT TANAH ADAT DI KANTOR PERTANAHAN KOTA SORONG
}

\author{
Muhammad Ridha Suaib \\ Fakultas Ilmu Sosial dan Ilmu Politik, Universitas Muhammadiyah Sorong \\ Email: muhammadridhasuaib@gmail.com
}

\begin{abstract}
ABSTRAK
Masyarakat adalah pihak yang menjadi sasaran kebijakan, sehingga kepada masyarakatlah keberhasilan kebijakan itu harus ditanyakan. Penelitian ini bertujuan untuk mendeskripsikan Faktor-faktor yang menjadi pendukung dan penghambat dalam kebijakan pelayanan pengurusan sertifikat tanah adat di Kantor Pertanahan Kota Sorong. Penelitian ini menggunakan pendekatan deskriptif analisa, tehnik pengumpulan data dengan menggunakan wawancara, observasi dan dokumentasi. Hasil penelitian menunjukkan bahwa kebijakan pelayanan pengurusan sertifikat tanah adat pada Kantor Pertanahan Kota Sorong terdapat faktor pendukung dalam pelayanan pengurusan sertifikat tanah adat yaitu, adanya keamanan berkas mulai dari pengisian formulir, input, proses, output dan jaminan data, keamanan berkas, biaya yang diterapkan sesuai dengan aturan yang berlaku, tidak adanya pungli, serta pelayanan yang adil. Adapun faktor penghambat dalam pelayanan pengurusan sertifikat tanah di Kantor Pertanahan Kota Sorong yaitu, adanya ketidaksederhanaan dalam pelayanan, adanya ketidakjelasan dan ketidakpastian dalam layanan, tidak transparan di dalam menyampaikan informasi, serta adanya tindakan tidak efisiensi dalam pelayanan.
\end{abstract}

Kata Kunci: Kebijakan, Pelayanan, Sertifikat Tanah Adat.

\begin{abstract}
The community is the target of the policy, so it is to the public that the success of the policy should be asked. This study aims to describe the factors that become supporters and obstacles in the service policy of custom land certificate in the Land Office of Sorong City. This research uses descriptive approach of analysis, data collection technique by using interview, observation and documentation. The result of research indicates that the policy of service of land certificate in Sorong City Land Office is supporting factor in custom land certificate service, that is, the existence of file security from form filling, input, process, output and data guarantee, file security, with the prevailing rules, the absence of illegal levies, and fair service. The inhibiting factors in land certification services in the Land Office of Sorong City are the lack of simplicity in service, the lack of clarity and uncertainty in the service, not transparent in conveying information, and the lack of efficiency in the service.
\end{abstract}

Keywords: Policy, Service, Indigenous Land Certificate.

\section{PENDAHULUAN}

Permasalahan pertanahan di

Indonesia masih banyak bermasalah.

Menurut laporan Kementerian Agraria

terdapat $20,7 \%$ yang masih bermasalah

dilihat dari sengketa tanah atas status kepemilikan yang ganda, pendaftaran tanah yang belum terdaftar masih bersifat tanah ulayat dan penerbitan serifikat tanah masih banyak yang belum diterbitkan. Ini menunjukkan bahwa pelayanan publik yang diterapkan pemerintah sampai tahun 
2003 belum teraplikasikan dengan baik sesuai harapan publik.

Dengan pendaftaran hak atas tanah berarti pihak yang didaftar akan mengetahui subyek atas tanah dan obyek hak atas tanah yaitu mengenai orang yang menjadi pemegang hak atas tanah itu, letak tanahnya, batas-batas tanahnya serta panjang dan lebar tanah tersebut. Hasil akhir dari pendaftaran hak atas tanah dinamakan "Sertifikat Tanah". Untuk mewujudkan harapan-harapan yang ingin dicapai sebagaimana yang telah ditetapkan pada kebijaksanaan catur tertib bidang Pertanahan tersebut, maka dalam kenyataan praktek sehari-hari, kantor pertanahan sebagai institusi resmi pemerintah yang berwenang mengatur dan mengeluarkan sertifikat tanah, dalam melaksanakan tugasnya sehari-hari tidak luput dari perhatian publik berkaitan dengan kinerja pelayanan yang mereka berikan bagi masyarakat yang menggunakan jasanya. Permasalahan dalam hal pelayanan tersebut memiliki dimensi yang sangat luas dengan aneka ragam corak pelaksanaan di berbagai keadaan. Jika kita mampu mengukur kondisi kinerja pelayanan publik, dalam hal ini tentunya bukan hanya pada kantor pertanahan saja tetapi pada setiap institusi pemerintah yang secara langsung memberikan pelayanan publik yang berlaku dilingkungan masing-masing.

Salah satu sebab munculnya aneka ragam konflik pertanahan di Indonesia adalah strategi pembangunan nasional pada Pemerintah Orde Baru yang tidak menempatkan masalah restrukturisasi penguasaan tanah sebagai dasar pembangunan. Selain itu, penekanan pembangunan Indonesia diletakkan pada pencapaian petumbuhan ekonomi yang membawa konsekuensi adanya pembangunan kawasan industri dengan kebijakan Hak Guna Usaha (HGU) seperti Hak Pengusahaan Hutan (HPH), perkebunan dan transmigrasi yang membutuhkan tanah yang luas. Untuk kepentingan tersebut, maka terjadi pembebasan lahan/tanah dari para pemilik tanah ulayat setempat yang diikuti dengan adanya negoisasi mengenai harga tanah atau proses ganti rugi. Hal ini menjadi pemicu timbulnya banyak masalah di belakang hari. Misalnya konflik antara PT Timber Co (pemilik HPH) dengan masyarakat Suku Moi di Kota Sorong. Pangkal konflik tersebut adalah soal perizinan adat dari wakil-wakil suku Moi yang menguasai hutan adat di Desa Klayili dan sekitarnya yang dilanggar oleh PT Intimpura. Dalam perjanjian tersebut antara lain disebutkan: tim survei yang dibentuk Intimpura harus 
mengikutsertakan suku Moi;kemudian jenis kayu yang bisa menopang kehidupan suku Moi misalnya damar, lawan, dan cempedak tidak boleh ditebang; tempattempat yang dinyatakan keramat harus diberi tanda khusus dan tak disentuh mesin penebang. Demikian pula konflik antara Suku Moi dengan Pertamina. Pemicunya adalah ketidakpuasan suku Moi sebagai pemegang hak ulayat terhadap sikap dan perlakuan Pertamina yang tidak memperdulikan kesejahteraan warga sekitar daerah pengeboran minyak setempat.

Keadaan ini menunjukkan bahwa kebijakan negara di bidang pertanahan yang sejatinya melindungi hak-hak rakyat atas tanah, khususnya hak-hak masyarakat adat, ternyata malah melemahkan posisi masyarakat adat di mata penguasa negara dan pengusaha (investor). Masyarakat adat yang telah turun temurun mendiami suatu wilayah, kemudian secara sepihak pemerintah menetapkan wilayah tersebut sebagai kawasan hutan konservasi atau hutan tanaman industri dapat dengan sewenang-wenang diusir dengan alasan menjaga kelestarian lingkungan dan atau untuk peningkatan pendapatan daerah. Undang-Undang Pokok Agraria (UU PA) yang bervisi kerakyatan ditafsirkan sedemikian rupa guna mendukung penguasaan tanah (oleh negara secara langsung maupun tak langsung) untuk industrialisasi.

Kebijakan hukum yang berhubungan dengan pengakuan hak ulayat atas hutan adat ditelusuri dari Undang-Undang Dasar Negara Republik Indonesia Tahun 1945 Pasal 18B ayat (1) dan ayat (2) UUD NKRI Tahun 1945 menegaskan bahwa negara mengakui dan menghormati satuansatuan pemerintahan daerah yang bersifat khusus maupun istimewa dan negara mengakui dan menghormati kesatuankesatuan masyarakat hukum adat beserta hak-hak tradisionalnya sepanjang masih hidup sesuai perkembangan masyarakat dan prinsip-prinsip Negara Kesatuan Republik Indonesia yang diatur dalam Undang-Undang. Selanjutnya dalam Pasal 28I ayat (3) UUD NKRI Tahun 1945 menegaskan bahwa identitas budaya serta hak masyarakat tradisional dihormati selaras dengan perkembangan zaman dan peradaban. Beberapa pasal diatas merupakan dasar konstitusional dari otonomi khusus dan negara mengakui hakhak tradisional masyarakat hukum adat (Melani, 2015).

Masyarakat adalah pihak penilai yang paling berhak untuk memberi nilai, bukan aparat pelaksana kebijakan meskipun mereka tidak melakukan sejumlah penyimpangan dalam melaksanakannya. Masyarakat adalah 
pihak yang menjadi sasaran kebijakan, sehingga kepadanyalah keberhasilan kebijakan itu harus ditanyakan. Jika tidak demikian, maka sebuah keberhasilan kebijakan akan bernilai semu atau misleading karena hanya menunjukkan sejumlah deretan angka-angka mati yang sebenarnya tidak berbicara apa-apa jika disandingkan dengan kenyataan yang dirasakan masyarakat. Dalam perspektif ini masyarakat adalah pihak yang sangat penting dalam proses kebijakan, sehingga tujuan kebijakan yang ditetapkan itu selaras dengan apa yang dikehendaki oleh masyarakat. Munculnya sejumlah kasus dimana kebijakan diklaim bisa dilaksanakan dengan baik, tetapi masyarakat merasakan hal berbeda, meskipun tidak berseberangan secara diametral. Tidak jarang masyarakat menjadi pihak yang tidak menikmati kalau tidak dirugikan, meskipun kebijakan tersebut jika diukur berdasarkan proses dan prosedur tertentu dianggap berhasil karena tepat waktu dalam pelaksanaannya dan tidak ada satu sen uang yang diselewengkan (Rusli, 2013). Hak penguasaan tanah pada masyarakat adat disebut "hak ulayat". Terminologi "tanah ulayat" digunakan untuk menyebut tanahtanah yang dikuasai menurut hukum adat pada suatu etnik tertentu. Tanah ulayat suku adalah tanah-tanah yang dikuasai dan dikelola oleh suatu suku secara turun temurun, yang pengaturannya juga dikuasai oleh pemimpin/ketua suku tersebut. Pada perkembangan selanjutnya, tanah ulayat suku dapat menjadi tanah ulayat kaum, yang penggunaannya terbagi dalam keluarga-keluarga yang lingkupnya lebih kecil lagi.

Dalam kasus pelayanan pengurusan sertifikat tanah di Kota Sorong, perlu dipahami bahwa hak ulayat atas tanah adat telah diatur dalam lembaga adat. Hukum adat membagi wilayah tanah adat kepada marga-marga yang ada di suku Moi. Batasbatas wilayah kepemilikan tanah marga ditandai dengan berbagai benda alam, pohon kayu, sungai, batu, gunung, dan sebagainya. Setiap marga dalam suku Moi mengetahui batas-batas tanahnya, sehingga tidak bisa seenaknya masuk ke dusun atau tanah marga lain. Sebab setiap marga sudah memberikan benda keramat yang menjadi tanda tak terbantahkan atas kepemilikan tanah tersebut. Tujuan utama pelayanan publik adalah memenuhi kebutuhan masyarakat pengguna agar dapat memperoleh pelayanan yang diinginkan dan memuaskan. Karena itu penyedia layanan harus mampu mengidentifikasi kebutuhan dan keinginan warga negara, kemudian memberikan pelayanan sesuai dengan keinginan dan kebutuhan masyarakat tersebut. 
Dalam penyelenggaraan pelayanan, aparat birokrasi yang bertanggung jawab untuk itu senantiasa memperlihatkan sikap dan perilaku yang responsif ketika berhadapan dengan pengguna layanan yang datang. Dalam hal ini aparat birokrasi mampu memberikan penjelasan secara baik dan jelas tentang persyaratan administrasi yang diwajibkan untuk dipenuhi.

Hasil penelitian yang dilakukan oleh Mochtar dan Halili (2009) dengan judul', Tingkat Integritas Instansi Pelayanan BPN dan SAMSAT di Provinsi DIY', menunjukkan tingkat integritas instansi pelayanan BPN dan SAMSAT di Provinsi DIY belum maksimal dan ini dibuktikan dengan temuan di lapangan diantaranya seperti: tidak adanya kejelasan SOP, masih adanya pungutan liar, masih adanya pemberian tip, dan sering terjadi diskriminasi dalam pelayanan. Penelitian ini bertujuan untuk mendeskripsikan Faktor-faktor yang mempengaruhi kebijakan pelayanan pengurusan sertifikat tanah adat di Kantor Pertanahan Kota Sorong.

\section{METODE}

Penelitian ini menggunakan pendekatan kualitatif yaitu deskriptif analisis. Dalam penelitian deskriptif hanya menekankan, tidak berhak mengontrol keadaan, pada waktu dilakukan penelitian hanya bisa mengukur apa yang ada. Pelaksanaan metode penelitian deskriptif tidak terbatas hanya sampai pada pengumpulan dan penyusunan data, tetapi meliputi analisis dan interprestasi tentang arti data tersebut, selain itu semua yang dikumpulkan berkemungkinan menjadi kunci terhadap apa yang diteliti (Moleong, 1997). Teknik pengumpulan data yang digunakan dalam penelitian ini adalah wawancara, observasi dan dokumentasi. Di dalam rancangan penelitian kualitatif, fokus kajian penelitian dan atau pokok soal yang hendak diteliti mengandung penjelasan mengenai dimensi-dimensi apa yang menjadi pusat perhatian yang kelak dibahas secara mendalam (Bungin, 2003). Penelitian ini difokuskan pada faktor yang mempengaruhi pelayanan pengurusan sertifikat tanah adat di Kota Sorong.

\section{HASIL DAN PEMBAHASAN.}

Kebijakan tentunya juga dipengaruhi oleh berbagai hal, banyak yang mempengaruhi dalam pelaksanaan sebuah kebijakan, baik dari individu maupun dari struktur organisasinya (Mandala et al, 2016). Lebih lanjut, menurut Richard Rose dalam Winarno (2013) kebijakan adalah serangkaian kegiatan yang sedikit banyak berhubungan beserta konsekuensikonsekuensi bagi mereka yang bersangkutan daripada sebagai keputusan yang berdiri sendiri. 
Kebijakan pelayanan sertifikat tanah adat di Kantor Badan Pertanahan Kota Sorong Belum Optimal. Penelitian ini difokuskan pada kebijakan pelayanan pengurusan sertifikat tanah adat di Kantor Badan Pertanahan Kota Sorong yang dilihat berdasarkan Faktor-faktor yang mempengaruhi pelayanan pengurusan sertifikat tanah pada Badan Pertanahan.

Pelayanan publik yang diterapkan di Kantor Pertanahan Kota Sorong dalam pelaksanaan mekanisme prosedur teknis untuk mewujudkan pelayanan publik, dipengaruhi oleh adanya faktor yang mendukung dan menghambat pelayanan publik. Faktor-faktor tersebut berupa kesederhanaan, kejelasan dan kepastian, keamanan, keterbukaan, efisiensi, ekonomis dan keadilan atas pelayanan yang diberikan oleh aparat dan diterima oleh pemohon atau publik yang melakukan pengurusan sertifikat. Berdasarkan fakta yang terdapat di lapangan, maka untuk membahas masalah yang berkaitan dengan Faktor-faktor yang mempengaruhi kebijakan pelayanan pengurusan sertifikat tanah adat di Kantor Badan Pertanahan Kota Sorong dapat dijelaskan sebagai berikut:

\section{Kesederhanaan Pelayanan}

Kesederhanaan pelayanan sebagai faktor pendukung dan penghambat penerapan pelayanan yang diterapkan di
Kantor Pertanahan Kota Sorong. Sebagai pendukung apabila penerapan pelayanan sesuai dengan prosedur/tata cara pelayanan yang diselenggarakan secara mudah, lancar, cepat dan tidak berbelit-belit. Sebagai penghambat apabila penerapan pelayanan tidak memiliki prosedur SOP, pelayanan yang dipersulit, lambat dan terlalu birokrasi. Berdasarkan hasil penelitian disimpulkan bahwa dalam kegiatan pelayanan pengurusan administrasi pengurusan sertifikat di BPN, ada faktor penghambat dan pendukung. Faktor penghambat yaitu ketidaksederhanaan (prasyarat berbelitbelit), ketidakpastian dan kejelasan (waktu penyelesaian tidak jelas), tidak transparan (informasi dan data) dan tidak efisien (lama menunggu)

\section{Kejelasan dan Kepastian Pelayanan}

Kejelasan dan kepastian sebagai faktor pendukung dan penghambat kegiatan pelayanan yang diterapkan di Kantor Pertanahan Kota Sorong. Menjadi faktor pendukung apabila kegiatan pelayanan dijalankan dengan kejelasan prosedur pelayanannya, jelas dan pasti prasyarat yang harus dipenuhi, jelas dan pasti aparat yang melayani, adanya kepastian aparat yang bertanggungjawab melayani dan kepastian jadwal pelayanan penyelesaian. Menjadi faktor penghambat apabila kegiatan pelayanan tidak jelas 
secara prosedural pelayanannya, persyaratan teknis yang tidak pasti, unit kerja yang tidak jelas, tidak memiliki tanggungjawab sesuai dengan jadwal waktu penyelesaian pelayanan.

\section{Keamanan Pelayanan}

Keamanan pelayanan menjadi faktor pendukung dan penghambat dari kegiatan pelayanan yang diterapkan di Kantor Pertanahan Kota Sorong. Keamanan menjadi faktor pendukung apabila setiap kegiatan pelayanan terjamin input pelayanan, terjamin proses pelayanan, terjamin output pelayanan, terjamin kepastian legalitas hukum pelayanan dan terjamin dari kehilangan atau kerusakan berkas pelayanan. Keamanan menjadi faktor penghambat apabila kegiatan pelayanan tidak aman dari kesalahan input data berkas pelayanan, kesalahan atau kekeliruan melakukan proses pelayanan, kesalahan atau tidak lengkapnya output pelayanan yang diperoleh, tidak adanya jaminan ganti rugi atas kehilangan dan kerusakan akibat kelalaian aparat dalam melayani. Berdasarkan hasil penelitian bahwa faktor pendukung dari kegiatan pelayanan berupa keamanan berkas, pengenaan tarif biaya yang sesuai ketentuan yang berlaku dan pelayanan yang adil tanpa diskriminasi dan bersifat umum.

\section{Keterbukaan Pelayanan}

Keterbukaan pelayanan menjadi faktor pendukung dan penghambat kegiatan pelayanan yang diterapkan di Kantor Pertanahan Kota Sorong. Keterbukaan menjadi faktor pendukung apabila aparat memberikan informasi yang terbuka secara umum, menjelaskan pelayanan secara rinci tanpa ada kepentingan lain, memberikan keterbukaan dalam penetapan tarif atau biaya pelayanan, dan memiliki keterbukaan atas segala kekurangan dalam pelayanan yang diberikan. Keterbukaan menjadi faktor penghambat apabila aparat memberikan informasi yang tidak transparan secara umum, menjelaskan pelayanan yang tidak sesuai dengan SOP, melakukan pengenaan biaya yang tidak sesuai dengan aturan, dan tidak terbuka dalam menjelaskan keterbatasan layanan yang dimiliki.

\section{Efisiensi Pelayanan}

Efisiensi pelayanan menjadi faktor pendukung dan penghambat kegiatan pelayanan yang diterapkan di Kantor Pertanahan Kota Sorong. Sebagai faktor pendukung apabila pelayanan yang diberikan oleh aparat tepat waktu dalam penyelesaian, melayani sesuai prosedur yang berlaku, memberikan pelayanan terpadu dan melayani dengan tidak menunda berkas pelayanan, tidak efisien apabila pelayanan dilakukan oleh aparat dengan menggunakan waktu yang lama, 
melayani di luar ketentuan yang berlaku, melayani secara terpisah-pisah, dan melayani dengan menunda waktu kerja secara optimal. Ekonomis pelayanan menjadi faktor pendukung dan penghambat kegiatan pelayanan yang diterapkan di Kantor Pertanahan Kota Sorong. Sebagai faktor pendukung apabila aparat dalam memberikan pelayanan memberitahukan biaya yang dikeluarkan dalam pelayanan, memberitahukan ketentuan standar biaya yang dikenakan, menetapkan biaya yang terjangkau secara umum dan menghindari pungutan liar dari biaya yang tidak sesuai dengan aturan. Sebagai faktor penghambat apabila aparat tidak memberitahu biaya yang harus dikeluarkan dalam pelayanan yang tidak sesuai standar, dirasakan membebani dengan biaya yang tidak rasional, dan ada praktak pungli yang terselubung.

\section{Keadilan Pelayanan}

Keadilan pelayanan menjadi faktor pendukung dan penghambat kegiatan pelayanan yang diterapkan BPN. Sebagai faktor pendukung apabila pelayanan tersebut diberlakukan kepada setiap orang secara umum, tidak diskriminatif melayani, bersikap sama kepada semua pemohon yang dilayani dan melayani sesuai dengan aturan yang berlaku. Menjadi faktor penghambat apabila aparat melayani mendahulukan orang-orang tertentu, membeda-bedakan siapa yang dilayani, memprioritaskan orang yang dilayani dan menerapkan aturan tertentu kepada orang yang memiliki kepentingan dilayani. Selanjutnya efektivitas monitoring diterapkan melalui kegiatan inspeksi mendadak, memanfaatkan CCTV dan sistem pelaporan. Kemudian dilakukan evaluasi atas analisis data pelayanan, koreksi setiap kesalahan/penyimpangan, memberlakukan sanksi pelanggaran tugas berupa teguran dan hukuman, memberikan penghargaan prestasi berupa pujian, insentif dan promosi, serta melakukan inovasi atau terobosan untuk peningkatan.

Berdasarkan hasil pengamatan, untuk mewujudkan kualitas pelayanan salah satunya ditentukan oleh kualitas petugas loket. Hal ini diatur dalam Pasal 4 dan Pasal 5 Peraturan Kepala BPN Nomor 3 Tahun 2010 tentang Loket Pelayanan Pertanahan bahwa kualitas petugas meliputi aspek pengetahuan, keterampilan profesional, mentalitas, sikap dan disiplin petugas. Untuk mengetahui secara mendetail mengenai wujud pelayanan publik dalam pengurusan sertifikat tanah di Kota Sorong, peneliti melakukan wawancara dengan beberapa aparat yang terkait langsung dalam pelayanan pertanahan, hasil wawancara dengan aparat Kantor Pertanahan Kota Sorong 
telah berupaya untuk mengoptimalkan kegiatan pelayanannya kepada masyarakat yang belum mendaftarkan hak milik tanahnya untuk mendapatkan pelayanan sebagai bagian dari tugas pokok dan fungsi aparat untuk memberikan pelayanan pemenuhan hak atas tanah masyarakat yang datang mendaftarkan tanahnya untuk diterbitkan sertifikat kepemilikannya. Adapun hasil wawancara mengenai prosedur pelayanan sertifikat, diperoleh informasi bahwa aparat siap memberikan pelayanan kepada masyarakat yang melakukan permohonan untuk melakukan pengurusan penerbitan sertifikat tanah. Kegiatan pelayanan dijamin oleh aparat sepanjang masyarakat mengikuti SOP yang telah ditentukan mulai dari pendaftaran sampai pada penerbitan sertifikat dan pengaduan.

\section{KESIMPULAN DAN SARAN}

Berdasarkan uraian dan penjelasan di atas, dari penelitian ini dapat ditarik kesimpulan bahwa terdapat faktor pendukung dalam pelayanan pengurusan sertifikat tanah adat, yaitu; keamanan berkas mulai dari pengisian formulir, input, proses, output dan jaminan data berkas aman tidak ada yang hilang dan rusak, biaya yang diterapkan sesuai dengan aturan yang berlaku, tidak ada pungli dan penetapannya melalui penerbitan sertifikat tanah, serta pelayanan yang adil untuk semua orang, tidak diskriminatif dan terlayani. Adapun faktor penghambat dalam pelayanan pengurusan sertifikat tanah di Kantor Pertanahan Kota Sorong, yaitu; adanya ketidaksederhanaan pelayanan dengan alasan pelayanan terlalu prosedural mekanismenya, adanya ketidakjelasan dan tidak adanya kepastian penyelesaian layanan yang tepat waktu, tidak transparan di dalam menyampaikan informasi yang lengkap dan penambahan berkas yang harus dipersiapkan, serta adanya tidak efisien dalam memberikan pelayanan dikarenakan adanya perbenturan kepentingan layanan.

Diperlukan kajian yang lebih mendalam mengenai kebijakan pelayanan pengurusan tanah adat di Kota Sorong, mengingat persoalan pelayanan pengurusan tanah adat sangat krusial untuk ditangani dengan baik yaitu dengan memberikan pelayanan secara optimal kepada masyarakat.

\section{DAFTAR PUSTAKA}

Bungin, B. (2003). Analisa Data Penelitian. Jakarta: PT. Raja Grafindo Persada.

Edward Mandala, Rendra Setyahadirja, Jefri, Rio Renaldi, Nurul Mulyani. (2016). Implementasi Kebijakan Tentang Penerbitan Surat Persetujuan Berlayar. Jurnal Ilmu Pemerintahan . 
Moleong, L. J. (2000). Metodologi Penelitian Kualitatif. Bandung: Remaja Rosda Karya .

Merani, S. K. (2015). Implementasi Hak Menguasai Dari Negara Terhadap Pengakuan Hak Ulayat atas Hutan Adat Di Kabupaten Jayawijaya Provinsi Papua.

Mochtar Arifin Zainal, Asrul Halili. (2009). Tingkat Integritas Instansi Pelayanan BPN dan SAMSAT di Provinsi DIY. Yogyakarta: UGM.

Rusli, B. (2013). Kebijakan Publik (Membangun Kebijakan Publik Yang Responsif). Bandung: Hakim Publishing.

Winarno, B. (2011). Kebijakan Publik, Teori, Proses, dan Studi Kasus. Yogyakarta: CAPS.

\section{PROFIL SINGKAT}

Penulis bernama Dr. Muhammad

Ridha Suaib, M.Si. Penulis merupakan Dekan FISIP Universitas Muhammadiyah Sorong dan merupakan Alumni Program

Doktor Administrasi Publik Universitas Hasanuddin. Selain mengajar, penulis aktif sebagai peneliti, pengamat politik. Penulis merupakan Direktur The Papua Institute. Fokus kajian penelitian penulis yakni tata kelola pemerintahan dan kebijakan publik. 